\author{
Norbert ŻYCZYŃSKI ${ }^{1}$ \\ Anna NIZIOL ${ }^{2}$
}

\title{
WSPARCIE ANALIZY FOODCOST PRZEZ ZINTEGROWANY SYSTEM ZARZĄDZANIA
}

\begin{abstract}
Usprawnienia powstałe w wyniku zastosowania systemów informatycznych mają duże znaczenie dla zapewnienia zyskowności przedsiębiorstw gastronomicznych. Analiza wszystkich rodzajów kosztów wsparta rozwiązaniami informatycznymi dla bieżącej kontroli takich kosztów oraz umiejętność podejmowania na tej podstawie ekonomicznych decyzji może być źródłem przewagi konkurencyjnej. Ważnym elementem optymalizacji i kontroli w tym kontekście jest analiza FoodCost, której znaczenie opisano w artykule. Wykorzystano przykład zastosowania systemu informatycznego klasy ERP w obszarze wsparcia prowadzenia gospodarki magazynowej opartej na recepturach z uwzględnieniem inwentaryzacji okresowych. Mimo iż korzystanie z różnego typu systemów informatycznych jest coraz popularniejsze w wielu aspektach codziennego życia, a zwłaszcza ich wykorzystywanie do sprawnego prowadzenia biznesu, branża gastronomiczna często nie dostrzega korzyści, jakie mogą płynąć z wprowadzenia tego typu rozwiązań. Wynika to ze specyfiki branży, w której znakomitą większość stanowią przedsiębiorstwa małe, których właściciele mają często fałszywe przekonanie, że w związku z niewielką ilością personelu oraz powtarzalnością procesów są w stanie skutecznie zarządzać przedsiębiorstwem bez wsparcia systemu informatycznego. Dodatkowo pojawia się problem niewłaściwie postrzeganej oszczędności, gdzie decyzje podejmowane są w oparciu o koszt wdrożenia, a nie potencjalny zysk będący następstwem usprawnienia procesów. Celem artykułu jest przedstawienie zastosowania funkcji systemu informatycznego jako wsparcia w zarządzaniu przedsiębiorstwem gastronomicznym poprzez kontrolę kosztów. Zaprezentowany program pozwala na uzupełnienie analizy o wyliczenie wskaźnika FoodCost rzeczywistego, co przyczynia się do zmniejszenia liczby koniecznych inwentaryzacji czy też obniżenia ryzyka strat. Niniejszy artykuł w oparciu o przykład zastosowania przez badane przedsiębiorstwo systemu ERPwincash wskazuje, że wsparcie informatyczne znacznie ułatwia sprawne zarządzanie przedsiębiorstwem poprzez kontrolę kosztów wytworzenia produktów na podstawie receptur. W szczególności umożliwia precyzyjne określenie stosunku tych kosztów do przychodów ze sprzedaży.
\end{abstract}

Słowa kluczowe: koszty, analiza FoodCost, zarządzanie, gastronomia, program komputerowy

\section{WPROWADZENIE}

Współczesny rynek oraz działania konkurencyjne wymuszają na przedsiębiorstwach szukanie możliwości optymalizacji kosztów działalności. Podstawą w działalności gastro-

\footnotetext{
${ }^{1}$ Dr Norbert Życzyński (autor korespondencyjny), Katedra Systemów Zarządzania i Logistyki, Wydział Zarządzania, Politechnika Rzeszowska im. Ignacego Łukasiewicza, Al. Powstańców Warszawy 10, 35-959 Rzeszów; e-mail: n.zyczynski@prz.edu.pl

${ }^{2}$ Dr Anna Nizioł, Zakład Organizacji i Kształcenia Europejczyk, Uniwersytet Rzeszowski.
} 
nomicznej jest umiejętna kontrola ponoszonych kosztów. Analiza wszystkich rodzajów kosztów oraz umiejętność wyciągania wniosków i podejmowania na tej podstawie skutecznych decyzji jest zdecydowanym wsparciem w osiągnięciu sukcesu w prowadzonym biznesie. Zarządzanie kosztami w przedsiębiorstwie gastronomicznym nie powinno wyłącznie zmierzać do ich ograniczania, gdyż może to łatwo doprowadzić do obniżenia jakości produktów lub obsługi, a tym samym do spadku obrotów. Niezmiernie istotne jest w tym kontekście znalezienie idealnego bilansu między niskimi kosztami związanymi z prowadzoną działalnością a utrzymaniem odpowiedniej jakości, co wymaga umiejętności menadżerskich oraz profesjonalnej wiedzy zawodowej na temat rynku gastronomicznego oraz oferowanych produktów.

Rynek gastronomii w Polsce stale się rozwija. Wskazują na ten fakt dane Głównego Urzędu Statystycznego zawarte w „Małym Roczniku Statystycznym Polski 2017”, według których wzrasta liczba placówek gastronomicznych w kraju, szczególnie klasycznych restauracji (wzrost o 853 placówki w 2016 r. w stosunku do 2015 r. z poziomu 68342 do 69 195). Z kolei dane dotyczące przychodów z działalności gastronomicznej potwierdzają jednocześnie wzrost wartości rynku, który w 2016 r. wart był 34,5 mln zł³. Obserwuje się również wzrostowy trend w odwiedzaniu punktów gastronomicznych w ramach większości grup społeczno-demograficznych konsumentów, a głównymi kryteriami decydującymi o wyborze konkretnego punktu gastronomicznego są nadal jakość oraz przyzwyczajenie. Najważniejszym jednak czynnikiem decydującym o wizycie w danym punkcie i jednocześnie stanowiącym podstawową barierę, która nie pozwala części konsumentów korzystać z oferty gastronomicznej, pozostaje niezmiennie cena posiłków, a ta w sposób oczywisty jest determinowana przede wszystkim przez koszty produkcji ${ }^{4}$. Taki wniosek, wynikający z badań rynku gastronomicznego w Polsce, wskazuje na główną ideę w ekonomii gastronomii, którą powinno być dążenie przedsiębiorców do wyważenia pomiędzy optymalizacją kosztów a jakością serwowanego jedzenia.

Ważnym elementem optymalizacji i kontroli kosztów jest analiza FoodCost, czyli obliczanie kosztu surowców zużywanych do przygotowania potraw, szczególnie biorąc pod uwagę, że koszty surowcowe stanowią 30-40\% kosztów funkcjonowania gastronomii. Poziom FoodCost określa wynikający ze zużytych składników koszt sprzedaży, czyli jeden z najważniejszych (obok kosztów operacyjnych i kosztów personelu) obszarów wydatkowania w działalności gastronomicznej. Niewątpliwie sprawne zarządzanie tego typu kosztami stwarza szansę na maksymalizację zysków i zapewnienie stabilności działalności przedsiębiorstwa.

Niniejszy artykuł dotyczy zarządzania gastronomią poprzez koszty, wspartego rozwiązaniami informatycznymi dla bieżącej kontroli takich kosztów, co jest niezmiernie ważne nie tylko dla managerów gastronomii czy szefów kuchni, ale także dla wszystkich osób, które pragną efektywniej zarządzać biznesem gastronomicznym. Celem artykułu jest przedstawienie zastosowania funkcji systemu informatycznego jako wsparcia w zarządzaniu przedsiębiorstwem gastronomicznym poprzez kontrolę kosztów. Zaprezentowany program pozwala na uzupełnienie analizy o wyliczenie wskaźnika FoodCost rzeczywistego, co przyczynia się do zmniejszenia liczby koniecznych inwentaryzacji czy też obniżenia ryzyka strat. W opracowaniu wykorzystano przykład zastosowania programu informa-

\footnotetext{
3 „Rynek Gastronomiczny” i „Sweet\&Cofee” (wydanie specjalne czasopism), Warszawa 2017.

${ }^{4}$ GFK, 2016 rokiem dynamicznego rozwoju polskiej gastronomii, Komunikat prasowy, 12.01. 2017 r., GFK 2017, www.gfk.com [dostęp 10.11.2017 r.]
} 
tycznego ERPwincash w zakresie gospodarki magazynowej opartej na recepturach z uwzględnieniem inwentaryzacji okresowych. Pozwala to uzyskać dobry obraz stanów magazynowych konieczny do wykonywania regularnej analizy finansowej przedsiębiorstwa, która prowadzi do poprawy bieżącej kontroli nad kosztami. W przygotowaniu artykułu wykorzystano metodę studium przypadku oraz Desk Research, czyli analizę materiałów zastanych, dokumentów, stron www i materiałów archiwalnych, jak również technikę obserwacji.

\section{ZNACZENIE ANALIZY FOODCOST}

Koszty odgrywają ważną rolę w ocenie efektywności funkcjonowania przedsiębiorstw, dlatego warto w tym miejscu wyjaśnić czym są koszty. Zgodnie z ustawą o rachunkowości kosztami są ,uprawdopodobnione zmniejszenia w okresie sprawozdawczym korzyści ekonomicznych, o wiarygodnie określonej wartości, w formie zmniejszenia wartości aktywów, albo zwiększenia wartości zobowiązań i rezerw, które doprowadzą do zmniejszenia kapitału własnego lub zwiększenia jego niedoboru w inny sposób niż wycofanie środków przez udziałowców i właścicieli" ${ }^{5}$. W podobny sposób koszty definiują Międzynarodowe Standardy Rachunkowości, według których „,koszty są to zmniejszenia korzyści ekonomicznych w trakcie roku obrotowego w formie rozchodu lub spadku wartości aktywów albo powstania zobowiązań powodujące zmniejszenie kapitału własnego, z wyjątkiem podziału kapitału na rzecz właścicieli”" Koszty to również wyrażone w pieniądzu wykorzystanie czynników produkcji w formie celowej i ekwiwalentnej. Zużycie nieekwiwalentne, w wyniku którego nie powstają przydatne zjawiska, są traktowane jako straty z działalności gospodarczej ${ }^{7}$. Powyższe definicje wskazują na pewne cechy kosztów, które:

a) powodują zmniejszenie korzyści ekonomicznych w danym okresie sprawozdawczym,

b) przyczyniają się do zmniejszenia wartości aktywów lub zwiększenia wartości zobowiązań i rezerw,

c) powodują zmniejszenie kapitału własnego lub zwiększenie jego niedoboru w inny sposób, niż wycofanie środków przez udziałowców, właścicieli,

d) są rozłożone w czasie,

e) są odnoszone do uzyskanych przychodów ${ }^{8}$.

Ostatnia cecha wskazuje na to, że koszty ponoszone są niejako na poczet przyszłych przychodów. Gdyby nie chęć osiągnięcia przychodów, nie byłoby kosztów. Z punktu widzenia osiągania przychodów istotne jest to, aby koszty były możliwie jak najniższe.

Trudno wskazać przedsiębiorstwo, które w swojej działalności nie ponosiłoby kosztów. Informacje o nich tworzą podstawę procesów zarządzania, stanowią ważne kryterium podejmowania decyzji, są głównym wskaźnikiem charakteryzującym gospodarność przedsiębiorstwa, niestety są niewystarczające do sprawnego zarządzania ${ }^{9}$. Koszty obecne

\footnotetext{
5 Art. 3 ust. 1, pkt 31 ustawy z dnia 29.09.1994 r. o rachunkowości (Dz.U. z 2013 r., nr 330 ze zm.).

${ }^{6}$ E. Nowak, Rachunek kosztów przedsiębiorstwa, Wrocław 2010, s. 27.

${ }^{7}$ E. Nowak, Rachunkowość kurs podstawowy, Warszawa 2011, s. 197.

8 A. Czubakowska, W. Gabrusewicz, E. Nowak, Przychody, koszty, wynik finansowy przedsiębiorstwa, Warszawa 2009, s. 106.

${ }^{9}$ A.K. Koźmiński, W. Piotrowski (red.), Zarządzanie. Teoria i praktyka, Warszawa 2010, s. 62-89.
} 
są również w działalności gastronomicznej. Istotne zarówno w podejmowaniu decyzji, jak i planowaniu, a także kontroli nad kosztami, jest dokonywanie ich klasyfikacji głównie dla potrzeb wewnętrznych jednostki. Wybór odpowiedniej klasyfikacji kosztów jest przede wszystkim uzależniony od rodzaju decyzji podejmowanych w przedsiębiorstwie, form sprawowania kontroli, możliwości odszukania danych dostępnych o kosztach, a także od rodzaju prowadzonej działalności, czy rodzaju produkcji ${ }^{10}$. W celu skutecznego zarządzania kosztami w gastronomii dzieli się je na grupy rodzajowe ułatwiające analizę. Najczęściej stosuje się podział na koszty surowca (artykuły żywnościowe), koszty personelu (wynagrodzenia pracowników) oraz koszty operacyjne (pozostałe koszty) ${ }^{11}$. Specyfika poszczególnych kosztów powoduje, że do ich oceny stosuje się inne typy danych i wskaźniki. Ze względu na sposób reagowania kosztów na zmianę sprzedaży wyróżnia się koszty stałe, zmienne i mieszane. Każda spośród grup kosztów wpływa na wynik finansowy w inny sposób. Zazwyczaj najtrudniej kontroluje się koszty surowca, które są typowym przykładem kosztów zmiennych ponoszonych w celu przygotowania dań i napojów (mogą stanowić nawet $40 \%$ wartości sprzedaży). Zaliczane są również do kosztów bezpośrednich, co oznacza, że można je z dużą dokładnością przyporządkować do każdej jednostki sprzedaży, czyli konkretnego dania. Do kontroli kosztów surowca idealnie nadają się receptury stanowiące podstawowe narzędzie umożliwiające sprawdzenie, czy produkty żywnościowe są wykorzystywane prawidłowo i w odpowiednich ilościach. Ocena kosztów surowców spożywczych w oparciu o zdefiniowane receptury wytwarzanych dań pozwala określić FoodCost potencjalny, który jest prostym wskaźnikiem określającym opłacalność sprzedaży w zadanym okresie czasu lub też dla poszczególnych dań. Wskaźnik ten można wyliczyć z wzoru:

FoodCost potencjalny $=($ koszt składników/ sprzedaż dań gotowych $)$ x $100 \%$

W powyższym wzorze koszt składników wyliczany jest na podstawie receptury badanego dania gotowego, lub też wszystkich dań w zadanym okresie czasu. Otrzymany wynik podzielony przez sumę sprzedaży badanych dań, a następnie wyrażony w procentach, daje nam procentowy udział kosztów surowców/półproduktów w sprzedaży, czyli właśnie FoodCost. Umożliwia to szybkie pokazanie marż w oparciu o koszt surowca dla poszczególnych dań gotowych. Tak obliczony FoodCost potencjalny, szczególnie w odniesieniu do całej sprzedaży w zadanym okresie czasu, może w sposób niewystarczająco dokładny wskazywać faktyczny poziom wydatków, jakie ponosi przedsiębiorstwo. Należy pamiętać o różnych czynnikach, które mogą wpływać na poziom kosztów surowców, jak na przykład straty będące skutkiem marnotrawstwa, kradzieże, zmiany cen składników, ubytek naturalny w procesie produkcji, indywidualny styl przygotowywania dań, dania bez receptur, dania gratisowe i inne. Zdaniem C. Ojugo od 22-25\% wariancji kosztów żywności jest wynikiem strat poniesionych podczas produkcji kuchennej ${ }^{12}$. Dlatego też dokładniejszym, ale jednocześnie bardziej czasochłonnym wskaźnikiem, jest FoodCost rzeczywisty, to znaczy koszt surowca obliczany w oparciu o inwentaryzację przeprowadzoną na początek oraz na koniec badanego okresu. W takim przypadku ilość oraz wartość magazynu wynikająca $z$ inwentaryzacji początkowej oraz receptur i innych ruchów magazynowych

${ }^{10}$ B. Gierusz, Podręcznik samodzielnej nauki księgowania, Gdańsk 2011, s. 390.

11 Zarządanie-w-Gastronomii-cz-2.pdf, http://restaurantmanager.biz (dostęp: 10.11.2017 r.).

12 C. Ojugo, Practical Food\&Beverage Cost Control, Second edition, Delmar 2010, s 197. 
korygowana jest inwentaryzacją końcową. Otrzymany wynik dzielimy przez sumę sprzedaży w danym okresie i w ten sposób otrzymujemy tzw. globalny FoodCost rzeczywisty. Ta metoda kontroli zużycia surowców spożywczych obok niewątpliwych zalet ma też pewne wady. Między innymi wszystkie surowce wyrażane w PLN trafiają do jednego wskaźnika zużycia surowców kuchennych (na przykład brokuł obok schabu). W ramach uzupełnienia tej metody wskazane jest zatem korzystanie $\mathrm{z}$ dodatkowych form kontroli, na przykład inwentaryzacji dziennej dla losowo wybranych surowców ${ }^{13}$.

\section{WSPARCIE ANALIZY FOODCOST PRZEZ ZINTEGROWANY SYSTEM ZARZĄDZANIA}

Ręczne wyliczenie zużytych do przygotowania danego dania składników w oparciu o receptury wymaga dużej wiedzy oraz znacznych nakładów czasu i środków, dlatego też określenie wartości FoodCost dla pojedynczego dania czy też dla całej sprzedaży w zadanym okresie byłoby bardzo trudne bez wsparcia informatycznego. L.R. Dopson i D.K. Hayes ${ }^{14}$ wskazują na metodę procentowego wyliczania FoodCost jako najstarszą i najbardziej tradycyjną ale też współcześnie już niedoskonałą w ustalaniu m.in. zawartości menu. Wdrożenie nowoczesnego systemu informatycznego w znacznym stopniu upraszcza proces rozliczania zużycia surowców na podstawie wcześniej zdefiniowanych receptur i tym samym umożliwia lepszą kontrolę stanów magazynowych w oparciu o wewnętrzne rozchody związane z przygotowaniem produktów do sprzedaży oraz inne ruchy magazynowe. Bieżąca systemowa kontrola stanów magazynowych w oparciu o receptury daje zbliżony do rzeczywistego stan magazynu. Okresowa inwentaryzacja określa natomiast faktyczne zużycie surowców, co daje możliwość weryfikacji poprawności receptur oraz ich dostosowania do rzeczywistego zużycia.

W badanym przedsiębiorstwie definicja nowego artykułu wykonywana jest w centralnym module BackOffice i podzielona jest na kilka sekcji. Na początku użytkownik definiuje podstawowe parametry nowego artykułu, takie jak nazwa, jednostka, sugerowana cena sprzedaży, czy też stawka podatku VAT. Jeżeli artykuł będzie magazynowany, użytkownik wybiera procesy, $w$ jakich definiowany towar będzie używany $w$ danym magazynie, a także określa dla każdego magazynu wartości minimalne, maksymalne i optymalne, ma również możliwość dopuszczenia stanów ujemnych. Użytkownik ma też możliwość przyporządkowania do artykułu dowolnej ilości kodów kreskowych oraz jednostek, co jest szczególnie istotne w przypadku surowców oraz zewnętrznie kupowanych produktów gotowych i półproduktów, gdyż umożliwia to zamawianie i składowane towaru w różnych jednostkach zbiorczych.

Wprowadzenie towaru do systemu odbywa się w kilku krokach. Użytkownik tworzy nowy dokument zamówienia. W tym przypadku może również skorzystać z wcześniej zdefiniowanych algorytmów zamówienniczych czy też zbadać obroty w zadanym okresie lub też - w przypadku przedsiębiorstwa wielooddziałowego o rozproszonej geograficznie strukturze - sprawdzić stany innych magazynów. Jeżeli zostały zdefiniowane dla danego artykułu różne opakowania, użytkownik ma możliwość podglądu przelicznika jednostek do zamówienia. Odpowiedni parametr systemu pozwala na automatyczne uzupełnienie

${ }^{13}$ G. Jaszkiewicz, Szybciej i sprawniej, „Nowości Gastronomiczne” nr 1/2010, 10 lutego 2010 r.

${ }^{14}$ L.R. Dopson, D.K. Hayes, Food and Beverage Cost Control, Fifth edition, New Jersey 2011, s. 405. 
wprowadzonej ilości do poziomu wymaganego przez wybranego dostawcę dla danej jednostki.

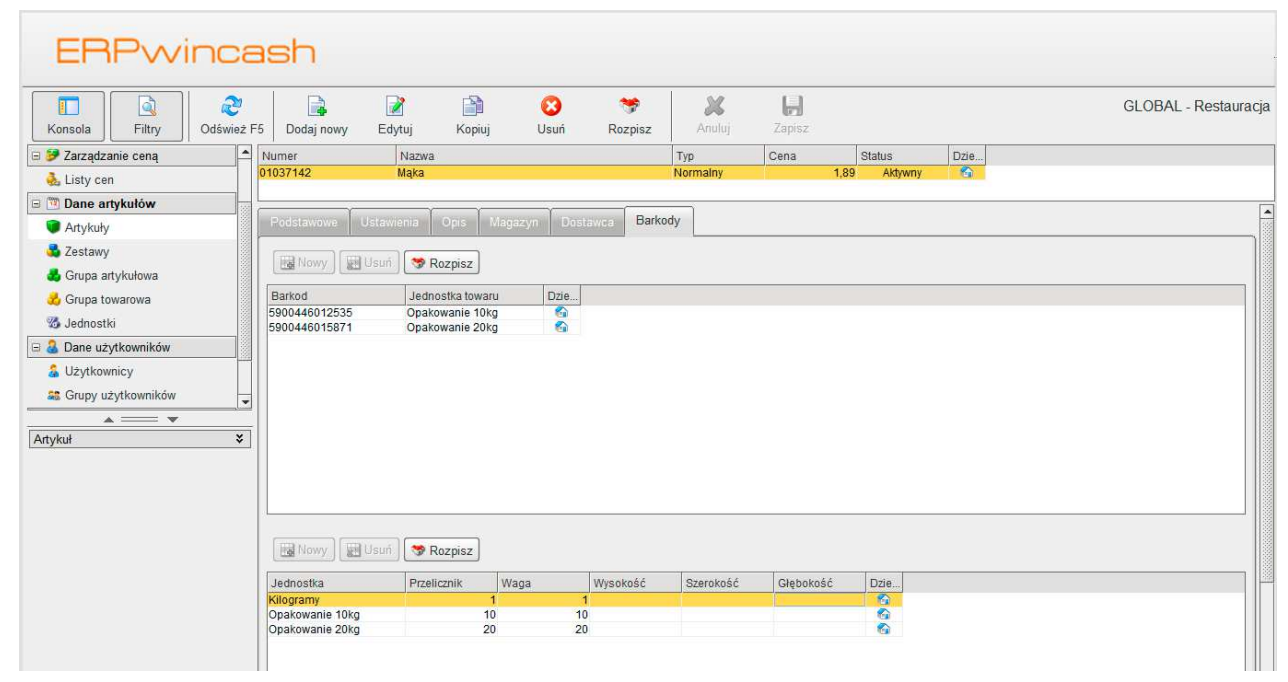

Rys. 1. Definicja jednostek dla towaru

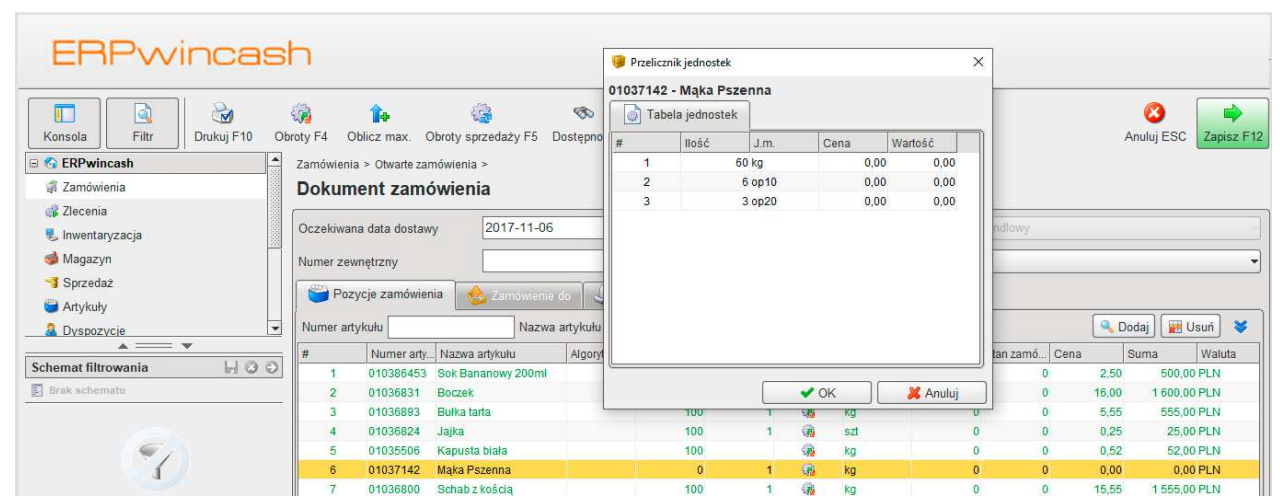

Rys. 2. Podgląd przelicznika jednostek dla zamówienia

Również podczas przyjęcia towaru od dostawcy istnieje możliwość wyboru odpowiedniej jednostki. Dodatkowo podczas przyjęcia można szybko zaznaczyć daną pozycję jako nadwyżkę czy też towar uszkodzony. W oknie podglądu aktualnych stanów magazynowych użytkownik widzi stany wybranego magazynu z podziałem na ilość dostępną, zarezerwowaną, zamówioną, awizowaną przez dostawcę w jednostce bazowej.

W przypadku towaru będącego wynikiem receptury definicja opiera się o określenie jego komponentów oraz czynności wykonywanych przy ich użyciu w trakcie produkcji. Definicja określa ilość potrzebną do wyprodukowania jednostki gotowego towaru, czyli 
na przykład sztuki. Poszczególnym komponentom przyporządkowana jest ilość potrzebna do produkcji. Na podstawie tak określonych parametrów system będzie wykonywał odpowiednie ruchy magazynowe na komponentach prowadzące do odpowiedniego zmniejszenia jego ilości.

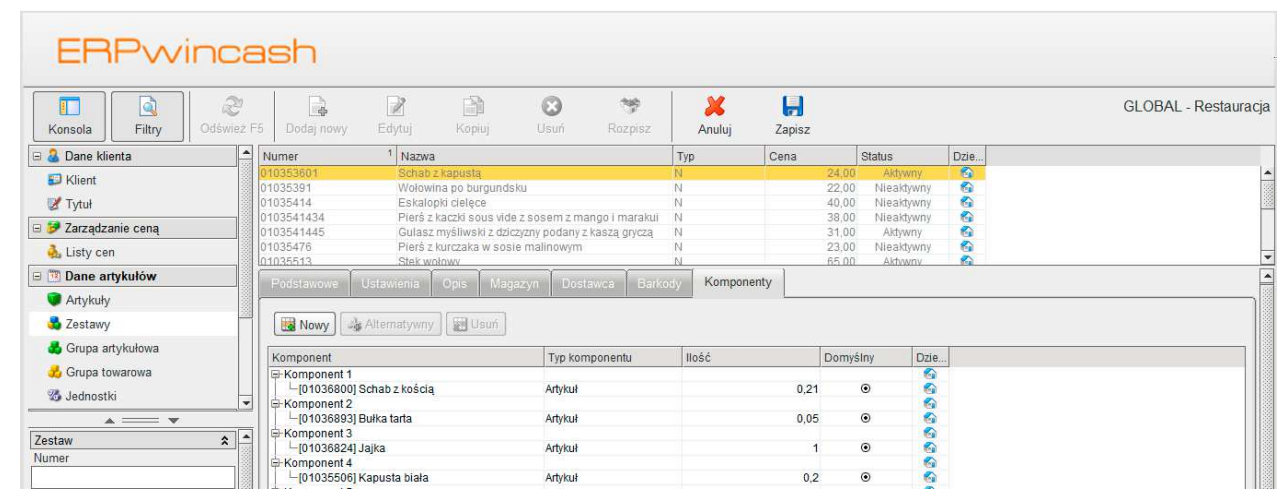

Rys. 3. Definicja komponentów towaru produkowanego

W oknie podglądu artykułów użytkownik ma możliwość podglądu receptury z uwzględnieniem aktualnego stanu magazynowego wszystkich wymaganych komponentów.

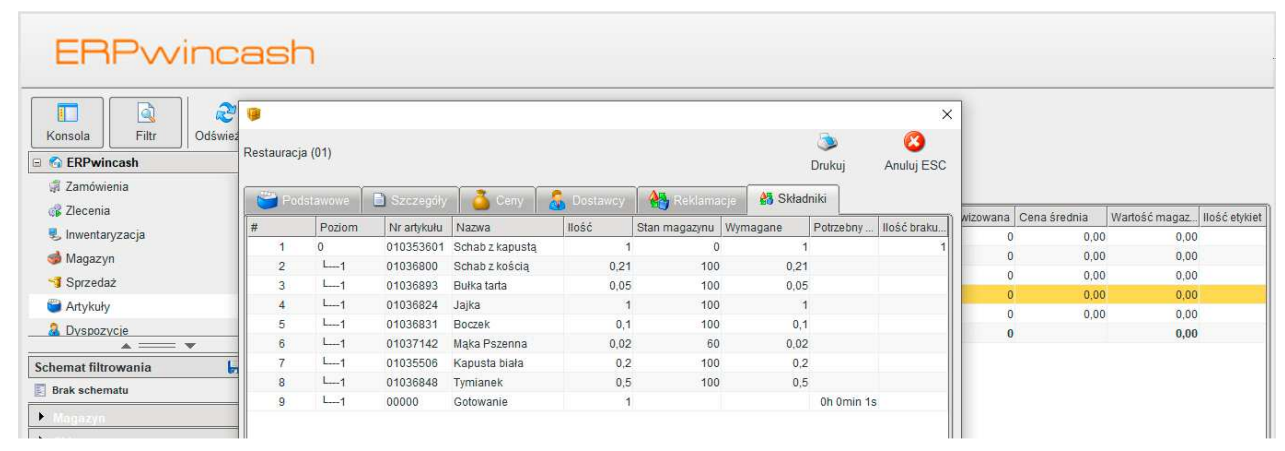

Rys. 4. Podgląd składników towaru produkowanego

Podczas sprzedaży system zapisuje w bazie danych wszystkie niezbędne kroki produkcyjne wynikające $\mathrm{z}$ aktywnych receptur sprzedawanych produktów. W dowolnym czasie użytkownik ma możliwość zatwierdzenia takiej produkcji. Zatwierdzenie może też zostać wykonane automatycznie dla wszystkich transakcji w zadanym okresie czasu.

W oparciu o zatwierdzoną produkcję system wystawia dokumenty rozchodu, korygując jednocześnie stan magazynowy zużytych w procedurze komponentów. Wszystkie te dokumenty, które zostały wystawione w oparciu o receptury, stanowią podstawę do obliczenia wskaźnika FoodCost. 


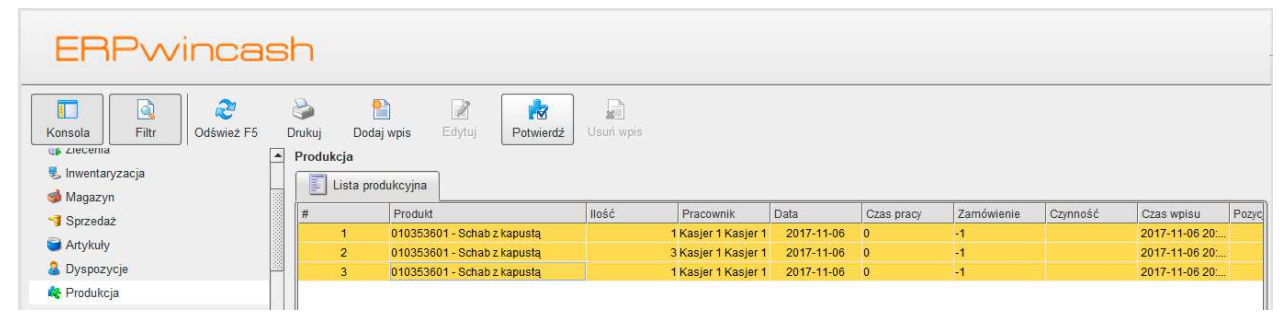

Rys. 5. Zatwierdzanie produkcji na podstawie sprzedaży

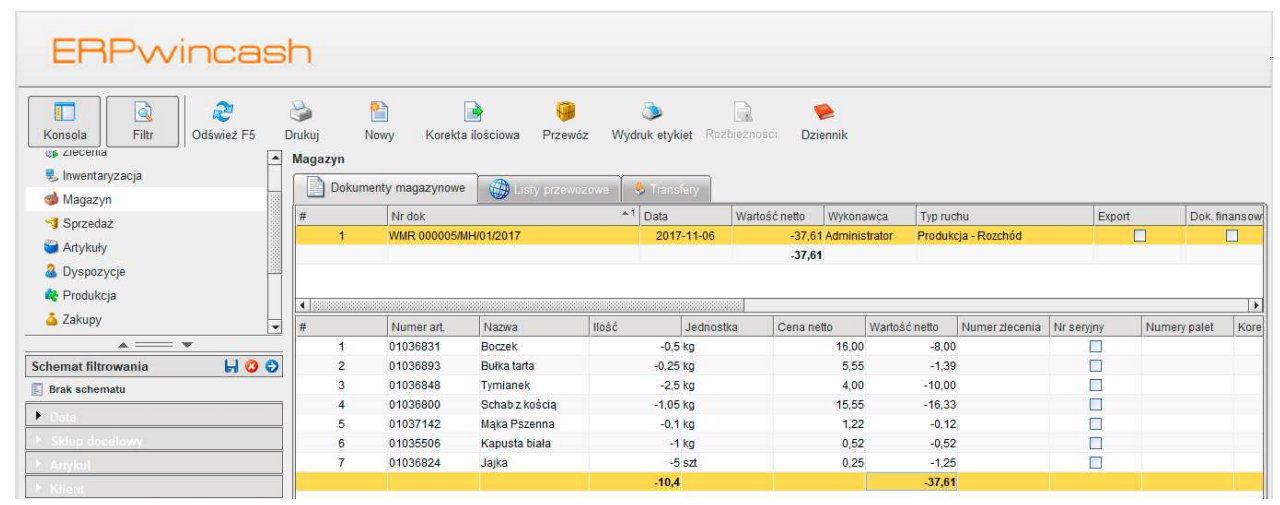

Rys. 6. Dokument rozchodu powstały w oparciu o zatwierdzoną produkcję

Dla poprawnego wykonania obliczeń niezbędnym elementem jest obliczenie faktycznej wartości magazynu na podstawie inwentaryzacji. Inwentaryzacja musi zostać wykonana na początek oraz na zakończenie badanego okresu. Wdrożony w badanym przedsiębiorstwie system umożliwia przeprowadzanie zarówno inwentaryzacji częściowej, jak i całościowej.

Użytkownik ma możliwość podglądu aktualnie trwającej inwentaryzacji, a po jej zatwierdzeniu w systemie generowane są dokumenty przychodu i rozchodu w zależności od faktycznego stanu magazynu w stosunku do wartości systemowej. Wynik inwentaryzacji wpływa na wyliczoną wcześniej wartość FoodCost dla badanego okresu, korygując go dla wszystkich odnalezionych nieprawidłowości. Wartość magazynu po zaksięgowaniu inwentaryzacji końcowej odpowiada zatem stanowi faktycznemu.

Wsparcie informatyczne jest coraz popularniejszą formą zarządzania, jednak nadal wielu właścicieli nie jest przekonanych do tego sposobu udoskonalenia działalności. Takie podejście jest podyktowane źle pojmowaną formą oszczędności, czy też przekonaniem, że małe przedsiębiorstwo nie potrzebuje tego typu usług. Tymczasem w wyniku szybko zachodzących zmian w otoczeniu przedsiębiorstwa oraz rozwoju technik, proces podejmowania decyzji ekonomicznych jest coraz trudniejszy. Potrzebna jest zatem systematyczna obserwacja powstających zmian w sytuacji wewnętrznej i zewnętrznej oraz 
ocena ich wpływu na możliwości rozwojowe jednostki ${ }^{15}$. Zapotrzebowanie na tego zakresu wiedzę wzrasta wraz ze stopniem skomplikowania procesów produkcyjnych, dlatego zastosowanie wsparcia informatycznego w tej materii zdecydowanie ułatwia zarządzanie przedsiębiorstwem i jego zasobami.

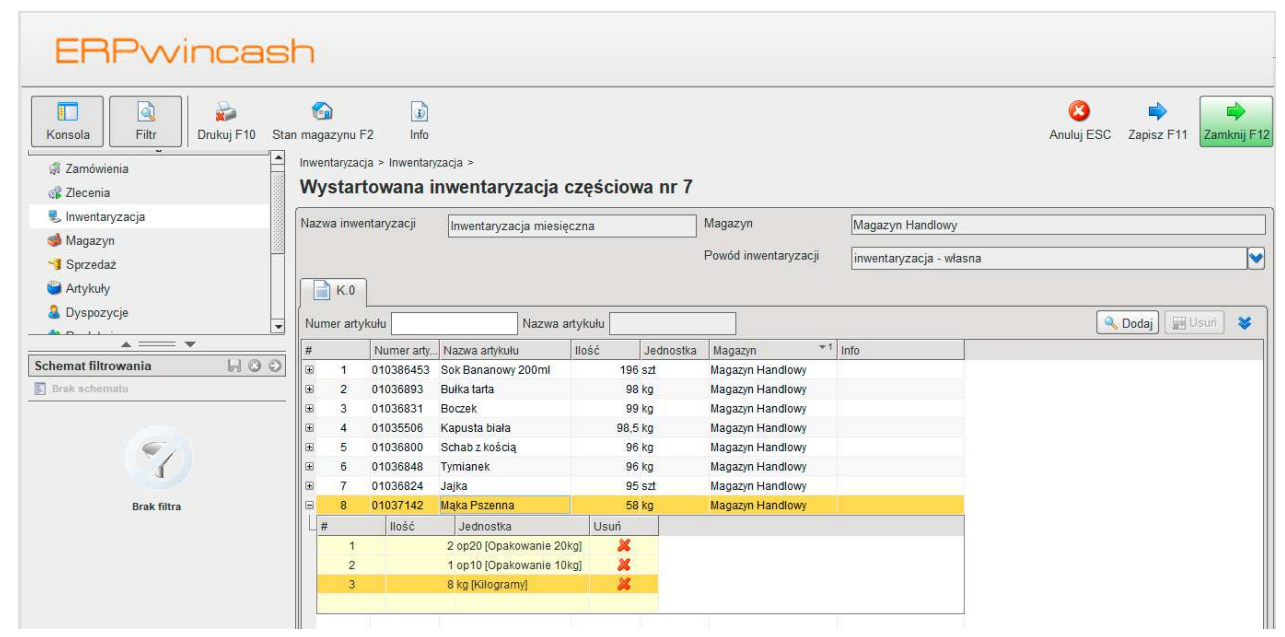

Rys. 7. Arkusz inwentaryzacji

Opisany w artykule przykład zastosowania programu informatycznego potwierdza korzyści stosowania rozwiązań informatycznych w celu poprawy bieżącej kontroli nad kosztami. Dzięki wdrożeniu systemu informatycznego możliwa jest między innymi ciągła i dokładna kontrola kosztów wytworzenia produktów gastronomicznych w oparciu o receptury, doprecyzowanie rachunku stosunku kosztów do wartości sprzedaży, określenie opłacalności sprzedaży konkretnego produktu zbliżone do rzeczywistego oraz wskazanie ewentualnych źródeł powstania problemów. Dodatkowo program pozwala na uzupełnienie analizy o wyliczenie wskaźnika FoodCost rzeczywistego, co przyczynia się do zmniejszenia liczby koniecznych inwentaryzacji czy też obniżenia ryzyka strat. Programy komputerowe niewątpliwie pomagają usprawnić produkcję, sprzedaż, logistykę i komunikację. Przedsiębiorstwa gastronomiczne korzystając $\mathrm{z}$ narzędzi i rozwiązań informatycznych zyskują przewagę konkurencyjną, lepsze możliwości zarządzania oraz dokładniejsze dane na swój temat ${ }^{16}$. Dynamiczny rozwój technologii informatycznych daje dodatkowe możliwości, a ich stosowanie przyczynia się do wzrostu wydajności, konkurencyjności, przejrzystości i dostępności przedsiębiorstw gastronomicznych.

15 W. Janik, Przedmiot, zadania i metody analizy ekonomicznej, [w:] Analiza ekonomiczna przedsiębiorstwa, red. W. Janik, M. Sosińska-Wit, Lublin 2003, s. 6.

16 E. Kubińska-Jabcoń, M. Niekurzak, Wykorzystanie narzędzi informatycznych we wspomaganiu procesów logistycznych $w$ zarządzaniu przedsiębiorstwem gastronomicznym, „Logistyka” 3/2014, s. 48. 


\title{
Literatura
}

[1] Czubakowska A., Gabrusewicz W., Nowak E., Przychody, koszty, wynik finansowy przedsiębiorstwa, PWE, Warszawa 2009.

[2] Dopson L.R., Hayes D.K., Food and Beverage Cost Control, Fifth edition, John Wiley \&Sons, Hoboken New Jersey 2011, s. 405.

[3] GFK, 2016 rokiem dynamicznego rozwoju polskiej gastronomii, Komunikat prasowy, 12.01.2017 r., GFK 2017, www.gfk.com (dostęp 10.11.2017 r.).

[4] Gierusz B., Podręcznik samodzielnej nauki księgowania, ODDiK, Gdańsk 2011.

[5] Janik W., Przedmiot, zadania i metody analizy ekonomicznej [w:] Analiza ekonomiczna przedsiębiorstwa, red. W. Janik, M. Sosińska-Wit, Wyd. Wyższej Szkoły Przedsiębiorczości i Administracji w Lublinie, Lublin 2003.

[6] Jaszkiewicz G., Szybciej i sprawniej, „Nowości Gastronomiczne” 1/2010, 10 lutego 2010.

[7] Koźmiński A.K., Piotrowski W. (red.), Zarządzanie. Teoria i praktyka, PWN, Warszawa 2010.

[8] Kubińska-Jabcoń E., Niekurzak M., Wykorzystanie narzędzi informatycznych we wspomaganiu procesów logistycznych $w$ zarządzaniu przedsiębiorstwem gastronomicznym, „Logistyka” 3/2014.

[9] Nowak E., Rachunek kosztów przedsiębiorstwa, Ekspert Wydawnictwo i Doradztwo, Wrocław 2010.

[10] Nowak E., Rachunkowość kurs podstawowy, PWE, Warszawa 2011.

[11] Ojugo C., Practical Food\&Beverage Cost Control, Second Edition, Cengage Learning, Delmar 2010, s 197.

[12] „Rynek Gastronomiczny” i „Sweet\&Cofee” (wydanie specjalne czasopism), BROG Marketing Sp. z o.o. S.K., Warszawa 2017.

[13] Ustawa z 29.09.1994 r. o rachunkowości (tekst jedn. Dz.U. z 2018 r., poz. 395).

[14] Zarządanie-w-Gastronomii-cz-2.pdf, http://restaurantmanager.biz (dostęp 10.11.2017 r.).

\section{SUPPORT OF FOODCOST ANALYSIS BY INTEGRATED MANAGEMENT SYSTEM}

\begin{abstract}
A computer program can improve key sectors in gastronomic companies. An analysis of all costs and an ability of making an effective decision on this basis is a definite business support. The important element of optimization and cost control is the FoodCost analysis is described in the article. The article deals with the management of gastronomy through costs, supported by IT solutions for the ongoing control of such costs. The example of the ERP class IT System is described in the area of support of warehouse management based on the recipes and periodic inventories. Although the use of various types of information systems is becoming more and more popular in many aspects of everyday life, especially in their use for efficient business operations, the gastronomic companies often overlook the benefits of introducing such solutions. This is because most companies from this sector are small businesses, whose owners often have a false belief that due to limited staff and repeatability of their processes, they are able to effectively manage the business without the support of an IT system. In addition, there is a problem of improperly defined savings, where decisions are based on the cost of implementation rather than the potential profit resulting from process improvement. This article, based on an example of an ERPwincash system implementation,
\end{abstract}


indicates that IT support improves management based by controlling the cost of producing products based on recipes. In particular, it allows to precisely define the ratio of these costs to sales revenue.

Keywords: costs, FoodCost analysis, management, catering, computer program

DOI: 10.7862/rz.2017.mmr.50

Tekst złożono $w$ redakcji: listopad $2017 \mathrm{r}$.

Przyjęto do druku: styczeń $2018 \mathrm{r}$. 
